\title{
Practices of Exception in Urban Governance: Reconfiguring Power Inside the State
}

Idalina Baptista

Sir Nigel Mobbs Research Fellow

Institute for Science, Innovation and Society, University of Oxford

64 Banbury Road, Oxford, OX2 6PN, United Kingdom

Phone: +44(0)1865288721

E-mail: idalina.baptista@insis.ox.ac.uk

\begin{abstract}
Supported on the analysis of a case study from Portugal (Polis Program), the article analyzes the use of legal practices of exception in urban governance to explore ongoing reconfiguration of relationships within the state. A growing number of studies address how practices of exception shape state-society relationships, but little attention has been paid to how they shape the relationships among those governing while eliciting antagonisms from dissenting state actors. Findings suggest that legal practices of exception reconfigure the relationships within the state because, by default, they seek to redefine the field of government through a redistribution of power. The article illustrates different ways in which state actors attempt to resist practices of exception in everyday practice and concludes with a discussion of three paradoxes of their use in urban governance. The article reasserts the relevance of studying the role of the law and of the bureaucracy in urban governance.
\end{abstract}

\section{Introduction}

This article analyzes the use of legal practices of exception in contemporary urban governance as a way of attending to the ongoing reconfiguration of relationships within the state. Here, 'practices of exception' are legal instruments defining special rules and procedures for specific urban governance situations.[1] Three aspects of the politics of exception matter to urban governance, beyond the exception itself: (1) the reasons and circumstances for the deployment of exceptions; (2) the temporary shifts or permanent mutations imposed by exceptions on the conditions of government; and (3) the ways in which an exception is resisted, appropriated and transformed.[2] This article foregrounds the intersection of the latter two aspects by paying attention to the forms of resistance used in everyday governance by state actors disallowed by practices of exception. Such focus reasserts the relevance of studying the role of the law and the inner dynamics of the state apparatus in contemporary of urban governance.

Urban scholars have seemingly fallen out of love with the legal aspects of urban governance, either dismissing them or taking their role for granted (Fernandes and Varley, 1998). Yet, pressed for flexibilization, governments have kept on mobilizing the law in exceptional ways to redefine the field of government and the spaces (and bodies) to be governed. For example, authors like Neil Smith (2002) and Erik Swyngedouw 
(1996) note that processes of neoliberal urban restructuring in the U.S. and Europe often involve new forms of authoritarianism, the wearing down of democratic control, and the selective limitation of citizenship rights. In discussing the 'right to the city', David Harvey (2008) suggests that land grabs in the Global South proceed in the crucible of eminent domain laws, property rights and legalistic forms of displacement and dispossession. Aiwha Ong (2006) observes that some Asian states are making 'exceptions' to their legally instituted practices of territorial administration and spatial zoning in order to gain a competitive advantage in the global economy through the selective management of space and individuals.[3] Despite their diverse intellectual groundings, these observations illustrate that states deploy legal practices of exception to delineate new spaces of rule, temporarily or permanently administered in ways different from the rest of the territory.

Urban governance is no stranger to the use of practices of exception, both within and beyond the confines of existing legal frameworks. Long-standing examples of permissible exceptions within urban planning law worldwide include zoning variances and interim development controls (Freilich, 1971; Brough, 1974). Swyngedouw et al. (2002) count among the first to equate urban development partnerships with practices of exception. They argue that large-scale urban projects in Europe are being delivered "by means of 'exceptionality' measures, such as the freezing of conventional planning tools, bypassing statutory regulations and institutional bodies, the creation of project agencies with special or exceptional powers of intervention and decision-making, and/or a change in national or regional regulations" (ibidem, p. 543). The authors take a critical stance towards what they see as governance regimes that "lie at the margins" of statutory planning (ibid., p. 572) and involve a "significant redistribution of policy-making powers, competencies, and responsibilities" to "quasi-private and highly autonomous organizations" (ibid., p. 556). While the authors advance little about the specifics of practices of exception, their analysis substantiates the role played by practices of exception in redefining the conditions of contemporary urban governance.

Little attention has been paid to how legal practices of exception shape the relationships among those governing - i.e. the government, bureaucracies, and other state agents. This is not to say that the law has been purged from urban scholarship. For instance, as Salet (2002) suggests, the practice of urban planning and governance remains deeply intertwined with the application of the law and with due process. Nor is this to say that attention to the state is lacking in urban scholarship. Scholars have noted the territorial rescaling of the state (Brenner, 1999, 2004; Peck and Tickell, 2002); some have acknowledged the increasing importance of the local level for processes of neoliberal space production (Coaffee and Healey, 2003; Geddes, 2005); others have recognized the emergence of networked forms of governance that cut across the traditional national-local divide (Tewdwr-Jones and McNeill, 2000; Le Galès, 2001). Surprisingly, these studies tend to say little about bureaucracy's participation in contemporary urban governance as if it no longer mattered, or as if it had dissolved into some form of 'entrepreneurial governance'. If legal practices of exception are used to delineate new territorialities of rule, as posited above, they potentially generate temporary or permanent shifts of power among state agents. They concurrently redefine the roles played by, and the relationships among, different state actors, including the bureaucracy.[4] 
Understanding the transformative potential of legal practices of exception for the state apparatus requires attention to the ways in which they acquire meaning in practice (Edelman et al., 1999), to constitute a newly 'imagined' space of political rule (Brenner et al., 2003, p. 7). It demands the recognition of the performative nature of urban planning and governance in everyday practice, as an arena for power struggles and debate among competing discursive claims over the meaning and scope of planning problems and possible practical solutions (Healey, 1996, 2007; Hajer, 2005). A relevant focus of analytical attention is then the ways in which practices of exception come to be resisted and reinterpreted in everyday urban governance by different state actors.

Resistance by ordinary, subaltern, or marginalized subjects has been discussed at length in the literature, not least by reference to the works of Michel de Certeau (1984) and James Scott (1985), but few scholars have extended their insights to discussions of power struggles among state agencies (cf. Thomas and Davies, 2005; Feldman, 2008). De Certeau's work is relevant to contextualize how weaker actors may mobilize, from within the state apparatus, short-term, small-scale, everyday tactics to subvert legal practices of exception, reinterpreting their purposes, and taking advantage (albeit unsuccessfully) of the opportunities and openings created by it. Scott's study of peasants' everyday resistance to class domination also finds a parallel in hierarchical struggles within the state: because, in principle, subordinate agencies must comply with rules and follow the mandates of their hierarchical superiors, subversion of legal practices of exception may be possible only through adapted forms of 'foot dragging', false compliance, or sabotage. Expanding the work of both authors to the daily operation of the bureaucracy, Feldman (2008) discusses how short-term tactics can aid bureaucrats in the production of governing authority, even if only too frail. Her work calls attention to how actors 'dispossessed' of power by way of practices of exception may continue to assert some tenuous authority through short-term tactics, with no foreseeable long-term effectiveness. Thomas and Davies (2005) suggest that resistance to New Public Management discourse by public service professionals occurs through the exploitation of the looseness of its meaning. This points to the ways in which public service professionals use everyday resistance to claim a voice and re-imagine the new spaces of rule constituted by practices of exception. Approached through the lens of short-term everyday tactics and of the subversion and reinterpretation of meanings, the reconfiguration of relationships within the state through practices of exception occurs at the intersection of hierarchical authority and decentered forms of compliance and resistance (Foucault, 1977).

To explore the transformative potential of legal practices of exception in urban governance, the article explores their use by the Portuguese central government for the delivery of urban rehabilitation projects through urban development partnerships.[5] In 2000, the Portuguese Ministry of Environment established the Polis Program, an urban rehabilitation and environmental improvement program targeting run-down inner-city areas of thirty-nine cities and involving an estimated investment of nearly one billion Euros. Different central government agents questioned the discourse associated with the Program and its practices of exception, leading to a delayed implementation of the Program. This was the case in the city of Costa da Caparica, a popular beach-town in the vicinity of Lisbon, where the Polis Program was to have its largest and most expensive intervention. Over the nearly nine years documented here (1999-2007), the 
Polis Program was met with great discontent and resistance by the Nature Conservancy Institute, a public agency within the Ministry of Environment with significant jurisdiction in the area, whose authority was disallowed by the practices of exception adopted for the program.[6]

The article is organized in three sections. The first section provides a brief characterization of the practices of exception involved in the Polis Program, specifying policymakers' motivations for their deployment. The second section delves into the specific case of the Polis Program in the city of Costa da Caparica. Followed by a brief contextualization of the city, the section proceeds with an examination of instances of resistance by the Nature Conservancy Institute to the Polis practices of exception. The third section provides a concluding discussion of the relevance of using practices of exception as a lens to investigate the reconfiguration of relationships within the state and the conditions of contemporary urban governance.

\section{Justifying practices of exception for the Polis Program}

Mainstream EU-style, neoliberal ideas of city competitiveness and entrepreneurialism (European Commission, 1996, 1998, 1999) hit the wider Portuguese political agenda in 2000 when the Ministry of Environment of a newly elected Socialist government appropriated them into its flagship policy - the Polis Program. In the words of policymakers, the program was to have a "demonstration effect" of how "to make [a] city,"[7] following the perceived success of Lisbon's Eastern side renovation for the World Fair EXPO'98. While aggressive, market-driven neoliberal purposes and governance strategies were toned down in the conception and delivery of the EXPO urban project, a context-specific flavor of entrepreneurialism was evidently present (Cabral and Rato, 2003). The central government created a development company solely dedicated to the EXPO project, with exceptional planning and development control powers, and private-style management that contrasted with the rule-following behavior of central and local planning bureaucracies.

Policymakers believed that, if successfully replicated, the EXPO model could overcome the cumbersomeness of Portuguese planning bureaucracy and stimulate a new governance culture within municipalities. This would facilitate the achievement of the program's intent to correct previous "urban mistakes" (Correia, 2003). [8] The program was to be delivered between 2000 and 2006, a timeframe defined by the availability of an EU funding package for the same period. This meant that timely delivery of all Polis projects became a prime concern to policymakers.

In the name of greater efficiency, the Ministry of Environment deployed practices of exception to redefine standard planning and governance powers and jurisdictions. The Ministry proposed to the municipality of each participating city to partner up in local development partnerships, known as the Polis Societies.[9] The partnerships would temporarily take over national and municipal planning, development control and land appropriation powers for the duration of the program to assure the timely delivery of Polis projects. For constitutional reasons, if Polis Societies were to take on those powers, their transfer had to be legitimized by exceptional legal measures approved by 
the Portuguese Parliament. This procedural necessity facilitated the creation of territories of exceptional rule run by the partnerships and the reorganization of power within the state.

Policymakers used these exceptional measures to target the state's bureaucratic apparatus. The Polis exceptions were set up into two laws. One demarcated the city areas where the program would take place and temporarily suspending transformations within them. The other law, known as the Polis regime of exception, specified planning, management, and administrative powers temporarily transferred to the partnerships. It also established a temporary redistribution of responsibilities within the state apparatus regarding plan and project review procedures. Under current planning and development control laws, a Supervision Commission including interest groups and state agencies with jurisdiction in an area must favorably review plans and projects prior to their submission for municipal approval. These commissions have been highly criticized for their cumbersomeness, lack of pragmatism in decision-making, and a tendency for Commissioners to overstep the boundaries of their individual expertise (cf. Ferreira, 2005). Fears that the Supervision Commission would hamper the timely delivery of the Polis projects led policymakers to streamline the Supervision Commission's participation in the Polis Program. The Polis regime of exception established a ten-day deadline for the Supervision Commission to issue its formal review of plan and project proposals. To facilitate the timely accomplishment of the deadline, the regime limited the number of commissioners to five, appointing them in representation of each relevant ministry.[10] This presupposed that all agencies with jurisdiction and/or veto power over the area not directly represented at the Commission would diligently collaborate with their ministerial representative to issue their reviews in less than ten days.

In sum, the Polis regime of exception reorganized the power structures within the state apparatus by overriding existing bureaucratic jurisdictions, reassigning administrative responsibilities and practices, and concentrating decision-making in representatives appointed by the higher echelons of the central government and the municipal councils. In practice, the new stipulations created a new (but imagined) space of rule that made a clean slate out of institutionalized structures and practices. Overall, the Polis regime of exception reflected policymakers' confidence that establishing exceptional legal measures would suffice in taming the state's bureaucratic apparatus and in mobilizing all public agencies to the Program's timely delivery. Yet, this aspiration was actively contested from within the state itself. As the case of Costa da Caparica below illustrates, state agencies whose jurisdictions were overstepped found many reasons to resent and resist the Polis Program locally.

\section{Governing by exception: the Polis Program in Costa da Caparica}

While the Polis practices of exception may have been justified primarily on the heels of improved efficiency in plan and project delivery, in Costa da Caparica they served to disallow dissenting state agencies. This section first provides a brief overview of the urban problems the program sought to address. It serves to contextualize the exposition of confrontations between the local Polis Society and dissenting agencies presented later in the section. 
Known as the 'Sun Beach', Costa da Caparica is one of the most desirable beach destinations for Lisboners on weekends and summer months. The Municipality of Almada,[11] of which jurisdiction the city is part of, had long held the prospect of expanding the city's tourist base beyond Lisbon's weekenders. In the view of municipal officials, the unappealing urban environment of Costa da Caparica and enduring political turf frustrated those intents.

Initially a fishing settlement off the Atlantic coast, Costa da Caparica evolved earlier in the 20th-century into a low-density resort for Lisbon's privileged classes. In the 1960s, following the construction of a bridge connecting Lisbon to Almada, urban development boomed in Costa da Caparica. Along with second home and hotel construction, irregular occupation of underserviced state-owned forests, farmlands, and beach dunes became an attractive option for the least affluent classes. Over the years, residents in these settlements upgraded their housing units from makeshift shacks into self-built masonry units and ultimately managed to get provision of basic utilities. Some vacationers preferred camping to the confines of apartments and hotels. Popular among campers were several campgrounds and caravan parks (camping parks, for short) managed by local or regional cultural and recreational associations. These camping parks began locating on prime oceanfront land outside the urban center, making them vulnerable to coastal erosion. Today these camping parks cover an area of nearly eighty hectares and serve nearly 18,000 users, leading some locals to call them "tent cities" instead of camping sites. The democratization of the automobile in the 1980s generated yet another type of visitor: the commuting vacationer from the greater Lisbon area. An estimated 180,000 visitors circulate daily in local roads in summertime, fifteen times the city's population of 12,000 (CMA, 1998, p. 8). With scant public transit alternatives, congestion was a common feature of beachgoers' trips to Costa da Caparica. Beach parking, especially to the south of town, was crammed into improvised parking lots servicing oceanfront restaurants. However convenient the location of these facilities is to beachgoers, environmental specialists argued they contribute to coastal erosion and environmental degradation.

Different government institutions have played a central role over the years in producing the complex layering of urban issues identified above.[12] Both as regulators of land use and as joint landowners of nearly twenty-percent of Costa da Caparica, several central government agencies allowed the continued and irregular occupation of state lands over decades. Political turf between central government's agencies and the Municipality stifled concerted action since the 1980s. This was particularly the case after the central government classified nearly 1,600 hectares in Costa da Caparica as a state Protected Area and determined the development of a Coastal Plan defining special protection measures for the oceanfront in the 1990s. Relationships were particularly tense between the Municipality and the Nature Conservancy Institute, the public agency under the purview of the Ministry of Environment with jurisdiction over Caparica's Protected Area and the Coastal Plan. The Institute's conservation principles for the area and its problematic leadership were long in conflict with the developmentalist aspirations of the Municipality. On its end, the Municipality also juggled a delicate balance between its aspirations and those of its traditionally left wing, working-class constituency. In fact, a major urban overhaul in Costa da Caparica, as the one implied by the Polis Program, required the re-location of nearly 21,000 people, among residents 
of informal settlements and camping park users. The re-location was welcomed by many, but often labeled as favoring 'the big capital' of tourism investors, a soft reminder that working-class sentiments were well alive in the region.

\section{Redefined jurisdictions - (re)claiming a voice and authority}

In redefining the territorial jurisdiction for the Polis intervention and transferring decision-making to the local Polis Society, the introduction of practices of exception in Costa da Caparica sought to make a clean slate out of this highly contentious political context. The weakest link was the Nature Conservancy Institute, which had its authority transferred to the higher echelons of the Ministry of Environment, its hierarchical superior. The attempt to suppress their dissenting voice was clear in the process leading up to the development of the Polis Strategic Plan for Costa da Caparica.

A preliminary version of the Polis Program in Costa da Caparica was first announced in April 2000, with more modest intentions than what was envisioned in the Strategic Plan presented a year later. It was confined to the city's oceanfront, an area under planning by the Institute since 1997 for the aforementioned Coastal Plan. These earlier intents proposed to improve the profile of the city center to attract visitors by extending the existing waterfront promenade to the South, improving access and utilities infrastructures, and rehabilitating existing oceanfront restaurant and parking facilities. It also included dismantling a shanty settlement and housing its residents in public housing units on site, according to previous municipal plans. All the informal settlements, camping parks, and beach facilities to the South of the city were excluded from the initial Polis intervention.

Staff members at the Institute were startled both by the content of these proposals and, considering their jurisdiction over the area, by the fact that they had yet to be consulted. They immediately voiced their objection to all infrastructural improvements on the oceanfront that would endanger the expected dune recovery works under the Coastal Plan. Aligned with the latter interest, and perceiving the renewal impetus of the Polis Program, staff members proposed the removal of four camping parks from the oceanfront, thus saving them troublesome negotiations with the camping associations in the context of the Coastal Plan. The Municipality welcomed the suggestion, for it provided an opportunity to address a longstanding but politically thorny issue with its constituents. However, it later suggested the relocation of the camping parks to a nearby forest next to the Protected Area managed by the Institute, a suggestion that generated a lot of contention.

Attempts by Institute's members to voice their opinions and retain authority were not restricted to influencing the area targeted for redevelopment. They also attempted to reverse the terms of their (non) engagement in the program defined by the Polis regime of exception. They suggested holding weekly meetings with the Strategic Plan team and to formally review it prior to approval. They also suggested that the Institute should join the local Polis Society. However, policymakers at the Ministry of Environment met the Institute's calls for direct participation with disinterest. As one policymaker put it, "we knew [the Institute] would object to anything we proposed and suggest no alternative in return; so, if they were to say no, they'd better say it only at the end of it all." Charged by the impetus to achieve a full-blown renovation of Costa da Caparica, policymakers 
felt the Polis regime of exception provided them with a mandate to disavow the Institute's voice and to override its jurisdiction temporarily. In fact, while discussions were still ongoing between the Institute and the Strategic Plan team, policymakers at the Ministry decided to approve the Polis Strategic Plan in July 2001.

Over the nearly fourteen months that took the development of the Strategic Plan, many other areas of Costa da Caparica were included in the program and no agreement with the Institute was sought.[13] The Polis Program in Costa da Caparica became the largest, most expensive, and most complex of all Polis operations in the country. It covered an area of nearly 650 hectares, parceled into seven different plans, with an estimated investment of 215 million Euros. Among other projects, the Strategic Plan foresaw the relocation of a shanty settlement and of a large informal neighborhood, locally known as the Football Pitch Neighborhood. It also included the relocation of four camping parks and the rehabilitation of eight kilometers of beaches to the South of town, including access, parking, and restaurant facilities. All together, the Strategic Plan constituted a challenging task for the Polis Society to accomplish in six years, requiring the collaboration of multiple agencies with contentious past histories.

\section{Reassigning responsibilities - subverting power redistribution}

The Institute dealt with the Polis Program in a contradictory manner. While recognizing the legitimacy of the Ministry of Environment to mandate transformations in the area, it thought the program "had no legal [standing]; [that it was] a mere contract of intentions [between the Ministry and the] Municipality," as expressed by one of the Institute's members. The Institute's members also found perplexing that the Polis Program laid out a new set of planning units that did not match the pre-existing Costal Plan units. In their view, this only added "unnecessary turmoil" to an area already fraught by troubled institutional relationships. Both assertions reflect a tension between institutionalized practices and lines of authorities and the elusiveness of the Polis Program's newly created space of rule.

In this tension laid the possibility of contesting the program's redefinition of jurisdiction by manipulating opportunities provided by the Polis regime of exception. In fact, any land use transformation made by the Polis Society still required the approval of the Nature Conservancy Institute. This was because the regime of exception only transferred to the ministerial level the responsibility for participating in administrative planning procedures. The Institute effectively exploited this 'blind spot' of the regime of exception - the 'opening in the system,' as de Certeau would call it - to resist any proposals it disagreed with.

A few months into the process, the Institute continued to raise objections to the Polis Program and to put pressure on the Ministry of Environment to be closely involved in the affairs of the Polis Society. Seemingly unwilling to grant the Institute a seat at the Polis Society, the Ministry of Environment decided, in October 2001, to call the Institute and four other of its agencies to take part in an inter-agency Working Group. The group's mission was to discuss plans and projects under development, ahead of their formal review by the Ministry's representative at the Supervision Commission. This was to assure that no further discussions were necessary during the ten-day review period established for the Commission in the Polis regime of exception. 
In practice, the Working Group operated as an arena for members aligned with the Polis Society, including the Municipality, to regiment the voice of the Nature Conservative Institute into a unified discourse favorable to the program's intents. On their part, members of the Institute used these meetings and procedures to assert their points of view and to fight nearly every single change proposed to Costa da Caparica, even those that seemingly aligned with their interests. Their resistance tactics varied from determined and long-lasting opposition to concrete proposals, recanting from decisions achieved during the Working Group's meetings, or through procrastination in providing their formal reviews to plan and project proposals. The Polis regime of exception had no provisions for the cases when a member of the Supervision Commission issued a negative review or faltered to comply with the ten-day deadline. Unless the Institute issued a positive review on a specific plan or project, it remained unapproved. The later that decision came, the more difficult it was for the Polis Society to tap into EU funding to deliver the renovation of Caparica on time. Procrastination - a form of Scott's foot dragging and failed compliance - became a very useful, short-term resistance strategy.

One particular case in which procrastination played an important role in subverting the redistribution of power involved the plans to rehabilitate the oceanfront. The plan proposals advanced by the Polis Society included the relocation of the camping parks to a nearby forest area and of a local football pitch to another location (MAOT and CMA, 2001, p. 47). It also included the full restoration of the dune system and the construction of new housing for the residents of the adjacent informal settlement locally known as the Football Pitch Neighborhood (ibid.). The partnership hoped to finance these projects by selling off the vacated land to hotel developers. Overall, the partnership's proposals for the area attempted to strike a difficult balance between ecological sustainability and the provision of facilities to the increasing numbers of weekenders and summer visitors.

The intent to accommodate existing beachgoers' demand was contrary to the Institute's conservation principles for the area. The Institute argued against virtually every single detail of the proposals involved in the dune restoration project, claiming it was overly designed to accommodate beachgoers, too ambitious and too expensive to be successfully implemented. Polis officials deemed the Institute's assessment inconceivable and a blocking force to the restoration of the dune system. Either acting out of fear or seeking to preserve its control over the area, the Institute showed no signs of waning determination against the proposals of the Polis Society. Over a period of four years, between 2002 and 2006, the Institute's members repeatedly insisted on the righteousness of their assessment, taking many months to issue formal reviews. Ultimately, they forced the Polis Society to surrender to most of their demands, in face of mounting pressure to approve plans in time for application to EU funding. The Institute repeated this strategy in many other instances in which it disagreed with the proposals of the Polis Society, resorting to procrastination of decision-making as a tactic to reclaim its lost authority in face of a regime of exception that allowed for the reinterpretation of its territoriality of rule.

Another specific case of the Institute's attempt to retain its authority involved the relocation of the camping parks to a forest nearby the state Protected Area under their jurisdiction. Members of the Institute objected to the relocation due to the estimated size of the new campgrounds: large enough to accommodate an estimated number of 17,700 
campers. During the planning process, the Institute sought to reduce the number of campers allowed at the new campgrounds by resorting to their tactics of resistance. This time around, their capacity to assert authority was too frail and the plan was approved in early 2005. Unable to stop the campgrounds' location or capacity at the planning stage, the Institute attempted to stall its construction in the following stage: the mandatory environmental impact assessment (EIA) for the campgrounds construction project.

The Polis regime of exception had introduced new procedures for the approval of plans and projects as such, but established no changes regarding EIA procedures. Considering its jurisdiction in the area, the Institute held a seat at every EIA Review Commission responsible for analyzing the environmental viability of construction projects in Costa da Caparica. Unlike the Supervision Commission, the Institute had no intermediaries at the EIA Review Commission mediating their views or attempting to enforce the Polis agenda on them. Free to reign with its views, the Institute allied with other state agencies with a seat in the EIA Review Commission to short-circuit the new camping parks project. They agreed that a camping park for 17,700 users was preposterous and its need remained to be proven. They foresaw unacceptable environmental and social impacts in nearby densely populated areas, beaches, and the state Protected Area. The EIA Review Commission suggested that, if the Ministry of Environment chose to approve the project, then it should reduce the campgrounds' capacity to roughly 12,000 campers and require in advance the construction of a new roadway and accessibility improvements to the nearest beach. Ultimately, the Ministry of Environment approved the construction project conditioned to the fulfillment of all the aforementioned conditions proposed by the EIA Review Commission. This decision brought the Polis Program in Costa da Caparica to a halt because it tied the campgrounds' project to decisions outside the purview of the Polis Program - namely regarding the construction of the new roadway. In James Scott's terms, this tactic of resistance amounted to no less than sabotage.

\section{Temporary exceptions - permanent mutations}

Ten years on, in late 2011, the Polis Program in Costa da Caparica remained unfinished. This was not however just the doing of the Nature Conservancy Institute. Of the initial seven plans, three remained unapproved, and only two of the four approved had been completed. Local interest groups mobilized against proposals envisioned in the remaining plans, including opposition waged by the Municipality against other state agencies and interests. They too waged their strategies of resistance, but their account falls outside the remit of this article. The construction of the new roadway referred to in the EIA had been partially suspended due to the Portuguese sovereign debt crisis, and many other investments had been reevaluated due to funding cuts imposed by previous governments. The construction of the new camping parks had yet to start, not because the roadways remained unfinished, but because the compulsory acquisition of the forest area was being disputed in court. The local Polis Society had outlived its initial termination date (July 2007), a reminder that the temporary nature intended for the exceptional measures was then in effect for over ten years. As the Polis Society was expected to cease functions in 2013, it remained unclear whether the impetus for a full-blown urban renovation of Costa da Caparica that demonstrated how "to make [a] city" and "correct past urban mistakes" would ever be achieved. 
As others who resort to tactics of resistance, the Institute's ability to (re)claim a voice and the lost authority was at times productive, at times short-lived. Yet, its resistance had an unforeseen lasting impact on the relationships between state agencies in future planning processes. This was because of amendments introduced in 2007 by the Ministry of Environment to planning and urban development laws, following the Polis experience. Amendments provided members of public agencies appointed to the Supervision Commission with binding decision-making power and prohibited them from revoking decisions. If agencies failed to appoint a representative, attend Commission meetings, or issue their review within the established deadlines, their position was presumed in agreement with proposed plans and projects. Finally, the amendments limited the role of the Supervision Commission to the verification of proposals' compliance with administrative rules and legal regulations, and with existing plans. In attempting to clarify the legal and procedural rules for the operation of the Supervision Commission, the Ministry of Environment showed a willingness to suppress future tactical resistances and to enforce a strictly technocratic view of the planning process. Ultimately, the experiment with the practices of exception served to mutate the law that its selectively and temporarily modified and suspended.

\section{Conclusion}

This article looked at the use of legal practices of exception as a lens to investigate the ongoing reconfigurations within the state in contemporary urban governance. The case's findings suggest that legal practices of exception reconfigure the relationships within the state because, by default, they seek to redefine the field of government and the territoriality of rule through a redistribution of power. State actors, including less powerful ones, may resist these purposes in the face of hegemonic urban agendas they disagree with, or as a result of a loss of power within the established formal hierarchy. Resistance amounts to acts of reinterpretation and short-term tactics based on windows of opportunity found in the context of everyday governance. Their success may be short-lived, but will remain a way of (re)claiming a voice and authority, if only tenuously, in face of the reconfigurations imposed by exceptions.

The concern here is less the concrete success or failure of a given set of practices of exception and more what an analysis of its deployment reveals about the underlying dilemmas and conditions of contemporary urban governance. Pressed to generate more flexible structures of government, states have sought to redefine the field of government and the spaces (and bodies) to be governed. Practices of exception present the (imagined) possibility of making a clean slate out of complex institutional contexts by flexing the law's muscle. However, findings from the Polis Program's case suggest three paradoxes in the use of exceptions in urban governance.

First, the use of exceptions as tools of urban governance supposes they possess overarching and overriding power, yet exceptions are selective by nature. In the Polis Program case, policymakers framed the scope of the exception as a 'fix' to specific aspects of Portuguese urban planning and governance they deemed inefficient. Yet, policymakers expected the Polis regime of exception to operate as a blanket law that would override standard planning procedures. The everyday governance of the program 
brought to light several gaps - or 'blind spots' - of the legal exception. These gaps provided the windows of opportunity through which disallowed state agencies contested the exception. This outcome could be interpreted as a case of poorly designed legislation, troubled policy implementation, failed bureaucratic compliance, or conflicting interests among state agencies (cf. Pressman and Wildavsky, 1973; Lipsky, 1980). Such interpretations rely on the assumption that flawless policy and legislation design is possible, that planning and policymaking are 'rational' activities, or that greater politics always gets in the way of expertise. But perhaps this case reminds us that, with or without legal exceptions, urban governance remains a contested process that 'copes' as much as it 'muddles through'.

Second, the legality and legitimacy of exceptions rely on their temporary status, yet this runs counter to institutionalized practices of urban governance. Unlike standard legal frameworks designed for uniform application across the territory of the nation state, practices of exception seek to create temporary enclaves of rule. In the case analyzed here, the Polis regime of exception temporarily redefined local jurisdictions and reassigned responsibilities among state actors for plan- and project delivery. Despite local actors accepting, in principle, the legitimacy of the Polis exception to redistribute power temporarily, it sat uneasily with existing legal frameworks, administrative routines, and lines of authority. Practices of exception will, paradoxically but expectedly, entice antagonism by their very temporary nature. Their legitimacy will be questioned, even if only through instances of everyday governance. While scholars now show little interest in scrutinizing the legal aspects of urban planning and governance, this paradox justifies a call to a return to the study of the inner dynamics of the state apparatus in the context of urban governance.

Third, legal practices of exception seemingly provide an opportunity to eradicate dissent by decree, yet the possibility of defining exceptional measures is by default a political act. Through the Polis' exceptional measures, policymakers hoped to fence planning off from dissenting agencies, thus de-politicizing the process of urban change. The decision to eradicate dissent within the state apparatus through a legal exception can be understood only under a simplistic view of the bureaucracy as the dutiful implementer of policies from elected office. Instead, when closer attention is paid to the dynamics of everyday urban governance, policy implementation works at the intersection of hierarchical structures of authority and decentered logics of domination, resistance, and compliance. Interestingly, the disavowal of politics within the state elicits the same reaction as that expressed by social groups politically excluded by the state: a struggle for "one's voice to be heard and recognized as the voice of a legitimate partner," as Žižek (1999, p. 28) put it. This paradox problematizes contentions regarding the emergence of the post-political condition in contemporary urban policy (e.g. Swyngedouw, 2010). Discourses about the urban may attempt, in principle, to 'foreclose the political' (ibid.), but whether they succeeded remains to be seen.

A growing number of studies address how legal practices of exception reconfigure the relationship between the state and society in ways that often favor market-driven logics. Yet, beyond macro-structural interpretations of territorial state rescaling or network proliferation, we have paid little attention to how those same practices also reconfigure relationships within the state. The law remains fundamental in arbitrating jurisdictions 
and in regulating the operation and the legitimacy of state agents. Practices of exception seek to reshape these relationships only temporarily, contingently and selectively, shifting power inside the state, not necessarily 'hollowing it out'. If practices of exception are here to stay - or, at least, have become appealing tools in the pursuit of contemporary urban policy, as suggested earlier - then we cannot shy away from discussing what they mean to urban governance and to the transformation of places.

\section{Notes}

1 By talking about practices of exception, and not simply about exceptions, the article signals the understanding that legal instruments, taken as practices of law, reflect both a way of thinking and a way of doing (Bourdieu, 1977). Germane to the conceptualization of 'exceptions' in urban governance are discussions in legal-constitutional studies about the 'state of exception', namely by the controversial legal philosopher Carl Schmitt (2005 [1922]) on sovereign rule and the work of political philosopher Giorgio Agamben (1998) on 'bare life'. Schmitt's work and that of his critics (e.g. Mouffe 1999) helped conceptualize the article's theoretical grounding.

2 While the normative value of a legal framework lies on its expected application to the generality of situations, every legal framework also sets out the permissible exceptions to the rules it seeks to enforce (Pedro Sánchez, personal communication).

3 Ong (2006) illustrates how China deploys Special Administrative Regions and Special Economic Zones as "zoning technologies" to facilitate political unification with Hong Kong and Macao, and to facilitate economic integration with Chinese communities in Taiwan or Singapore in a context of globalization. Like the others, Ong places these enclosures of rule within the remit of neoliberalism, but seeing it as a technology of government applied by states, themselves not necessarily neoliberal, often in contradictory ways. Ong's attention to the contradictions of neoliberalism resonates with the call by Brenner and Theodore (2002) for a closer analysis of "actually existing neoliberalisms."

4 This transformative dynamics is in fact what underlies such claims as the "hollowing out of the state" (Rhodes, 1994).

5 Methodologically, this article is based on fieldwork conducted between March 2006 and February 2007 and during January 2008. I conducted a total of fifty-one semi-structured interviews with Polis officials, policymakers at the ministerial level, public officials at state agencies and the municipality, program and project managers, consultant teams and representatives of interest groups. In addition, I gathered official documents, agency records, and media accounts of the events related to the Polis Program. The research followed an interpretative approach to data collection and analysis and theory building. The process of building up interpretations proceeded through an iterative and interactive process of coding the variety of data collected, writing up narrative pieces of the meanings participants gave to different events, actions, and concrete objects (such as plans), and 
confronting interpretations with existing scholarly literature.

6 As it will become evident in the sections that follow, the two main players in conflict in this case are the Institute and the local Polis Society, but many other actors contributed to the dynamics of conflict that unfolded during the local implementation of this Polis Program. Covering all these stories in detail falls obviously outside the remit of this article, and in defining the central narrative for this article I have inevitably excluded many details and secondary players.

7 The Ministry of Environment defined a typology of urban projects to be implemented under the Polis Program that focused on the provision of public spaces for leisure, recreation, and consumption. For more details see MAOT (2000, p. 76-93).

8 I have argued elsewhere (Baptista 2011) against this derogatory reading of the Portuguese urban experience in what I call the 'unplanned country' narrative.

9 Polis Societies managed twenty-two of the thirty-nine Polis interventions and ten of them operated under the same model. My argument relies on a study of those ten Polis Societies.

10 From the five Commissioners, one was in representation of the Municipality and the remaining four were in representation of the most relevant Ministries (Environment, Public Works, Culture, and Finance).

11 The Municipality of Almada, one of the most populated municipalities of the Lisbon Metropolitan Area, is the institution that partnered with the Ministry of Environment for the Polis Program.

12 At the time of the program, at least six different central government institutions held some form of jurisdiction in the area: the Ministry of Finance, which controlled ownership of public properties; the Ministry of Agriculture, which had jurisdiction over the farmlands; three agencies under the Ministry of Environment with jurisdiction over natural and coastal areas; and the Lisbon Port Administration which had jurisdiction over the beach area.

13 Paradoxically, the Municipality demanded that Polis officials held several meetings with local community groups including the camping associations, so as to garner political agreement and support to the program. Some interviewees stated that the Municipality was not truly interested in having a genuine participatory planning process, suggesting that instances of public participation were mere window dressing. Other evidence suggests, however, that the Municipality sought an agreement with those local groups it identified as immediately affected by the Polis Strategic Plan. Evidence also suggests that other local community groups were simply informed of the Polis objectives. 


\section{Acknowledgements}

Research for this article was conducted with the support of a Doctoral Fellowship from Fundação para a Ciência e a Tecnologia, Portugal, under European Union's POCI 2010. The article was written during my time with the Oxford Programme for the Future of Cities as the Sir Nigel Mobbs Research Fellow. A special thank you to Pedro Sánchez for clarifications regarding the Portuguese legal system. For their comments on different versions of this article I thank the contributions of the journal's editor and referees, Gisa Weszkalnys, Javier Lezaun, Patsy Healey, Steve Rayner, and Tiago Castela.

\section{References}

Agamben, G. (1998) Homo Sacer: Sovereign Power and Bare Life. Stanford, CA: Stanford University Press.

Baptista, I. (2011) How Portugal became an 'unplanned country': a critique of scholarship on Portuguese urban development and planning, International Journal of Urban and Regional Research. Article first published online: 8 NOV 2011, DOI: 10.1111/j.1468-2427.2011. 01096.x.

Bourdieu, P. (1977) Outline of a Theory of Practice. Cambridge, UK: Cambridge University Press.

Brenner, N. (1999) Globalisation as reterritorialisation: The re-scaling of urban governance in the European Union, Urban Studies, 36, pp. 431-451.

Brenner, N. (2004) Urban governance and the production of new state spaces in western Europe, 1960-2000, Review of International Political Economy, 11, pp. 447-488.

Brenner, N. and Theodore, N. (2002) Cities and the Geographies of "Actually Existing Neoliberalism", Antipode, 34, pp. 349-379.

Brenner, N., Jessop, B., Jones, M. and MacLeod, G. (Ed.) (2003) State/Space: A Reader. Oxford, UK: Blackwell.

Brough, M. B. (1974) Flexibility without Arbitrariness in the Zoning System: Observations on North Carolina Special Exception and Zoning Amendment Cases, North Carolina Law Review, 53, pp. 925-958.

Cabral, J. and Rato, B. (2003) Urban Development for Competitiveness and Cohesion: The EXPO 98 Urban Project in Lisbon, in: F. Moulaert, A. Rodríguez and E. Swyngedouw (Ed.) The Globalized City: Economic Restructuring and Social Polarization in European Cities, pp. 209-228. Oxford, UK: Oxford University Press.

CMA (1998) Pacto para o Desenvolvimento Integrado da Costa de Caparica. Câmara Municipal de Almada, Almada, Portugal.

Coaffee, J. and Healey, P. (2003) 'My Voice: My Place': Tracking Transformations in Urban Governance, Urban Studies, 40, pp. 1979-1999.

Correia, F. N. (2003) Levar a Expo ao país todo (entrevista a Francisco Nunes Correia). By Manuel Graça Dias and Ana Vaz Milheiro, Jornal Arquitectos, pp. 9-17.

de Certeau, M. (1984) The Practice of Everyday Life. Berkeley, CA: University of California Press.

Edelman, L. B., Uggen, C. and Erlanger, H. S. (1999) The Endogeneity of Legal Regulation: Grievance Procedures as Rational Myth, The American Journal of Sociology, 105, pp. 406-454. 
European Commission (1996) European Sustainable Cities. Report by the Expert Group on the Urban Environment to the European Commission. European Commission, Brussels, Belgium.

European Commission (1998) Sustainable Urban Development in the European Union: A Framework for Action. European Commission, Brussels, Belgium.

European Commission (1999) ESDP - European Spatial Development Perspective: Towards a Balanced and Sustainable Development of the Territory of the European Union. European Commission, Luxembourg.

Feldman, I. (2008) Governing Gaza: Bureaucracy, Authority, and the Work of Rule, 1917-1967. Durham, NC: Duke University Press.

Fernandes, E. and Varley, A. (Ed.) (1998) Illegal Cities: Law and Urban Change in Developing Countries. London, UK: Zed Books Ltd.

Ferreira, A. F. (2005) Gestão Estratégica de Cidades e Regiões. Lisboa, Portugal: Fundação Calouste Gulbenkian.

Foucault, M. (1977). Discipline and Punish: The Birth of the Prison. New York, NY: Vintage Books Edition.

Freilich, R. H. (1971) Interim Development Controls, Journal of Urban Law, 49, pp. 65-119.

Geddes, M. (2005) Neoliberalism and Local Governance: Cross-National Perspectives and Speculations, Policy Studies, 26, pp. 359-377.

Hajer, M. (2005) Setting the Stage: A Dramaturgy of Policy Deliberation, Administration \& Society, 36, pp. 624-647.

Harvey, D. (2008) The Right to the City, New Left Review, 53, pp. 23-40.

Healey, P. (1996) The Communicative Work of Development Plans, in: S. J. Mandelbaum, L. Mazza and R. W. Burchell (Ed.) Explorations in Planning Theory, pp. 263-288. New Brunswick, NJ: Center for Urban Policy Research, Rutgers.

Healey, P. (2007) Urban Complexity and Spatial Strategies: Towards a Relational Planning for Our Times. New York, NY: Routledge.

Le Galès, P. (2001) Urban Governance and Policy Networks: On the Urban Political Boundedness of Policy Networks. A French Case Study, Public Administration, 79, pp. 167-184.

Lipsky, M. (1980) Street-level bureaucracy: the dilemmas of individuals in public service. New York, NY: Russell Sage Foundation.

MAOT (2000) Programa Polis, Programa de Requalificação Urbana e Valorização Ambiental de Cidades. Lisboa, Portugal: Ministério do Ambiente e do Ordenamento do Território.

MAOT and CMA (2001) Plano Estratégico - Viver a Costa de Caparica, Programa Polis. Lisboa, Portugal: Ministério do Ambiente e do Ordenamento do Território and Câmara Municipal de Almada.

Mouffe, C. (ed.) (1999) The Challenges of Carl Schmitt, Verso, New York, NY.

Moulaert, F., Rodríguez, A. and Swyngedouw, E. (Ed.) (2003) The Globalized City: Economic Restructuring and Social Polarization in European Cities. Oxford, UK: Oxford University Press.

Ong, A. (2006) Neoliberalism as Exception: Mutations in Citizenship and Sovereignty. Durham, NC: Duke University Press.

Peck, J. and Tickell, A. (2002) Neoliberalizing Space, Antipode, 34, pp. 380-404.

Pressman, J. L. and Wildavsky, A. (1973) Implementation: How Great Expectations in 
Washington Are Dashed in Oakland. Berkeley, CA: University of California Press.

Rhodes, R. A. W. (1994) The Hollowing Out of the State: The Changing Nature of the Public Service in Britain, The Political Quarterly, 65, pp. 138-151.

Salet, W. (2002) Evolving Institutions: An International Exploration into Planning and Law, Journal of Planning Education and Research, 22, pp. 26-35.

Schmitt, C. (2005 [1922]) Political Theology: Four Chapters on the Concept of Sovereignty. Chicago, IL: University of Chicago Press.

Scott, J. C. (1985) Weapons of the Weak: Everyday Forms of Resistance. New Haven, CT: Yale University Press.

Smith, N. (2002) New Globalism, New Urbanism: Gentrification as Global Urban Strategy, Antipode, 34, pp. 427-450.

Swyngedouw, E. (1996) Reconstructing citizenship, the re-scaling of the state and the new authoritarianism: closing the Belgian mines, Urban Studies, 33, pp. 1499-1521.

Swyngedouw, E., Moulaert, F. and Rodriguez, A. (2002) Neoliberal urbanization in Europe: large-scale urban development projects and the New Urban Policy, Antipode, 34, pp. 542-577.

Tewdwr-Jones, M. and McNeill, D. (2000) The politics of city-region planning and governance: reconciling the national, regional and urban in the competing voices of institutional restructuring, European Urban and Regional Studies, 7, pp. 119-134.

Thomas, R. and Davies, A. (2005) Theorizing the Micro-politics of Resistance: New Public Management and Managerial Identities in the UK Public Services, Organization Studies, 26, pp. 683-706.

Žižek, S. (1999) Carl Schmitt in the Age of Post-Politics. In C. Mouffe (ed.) The Challenges of Carl Schmitt. Verso, London, UK. 